\title{
Neotropical Entomology
}

ISSN: 1519-566X

journal homepage: www.scielo.br/ne

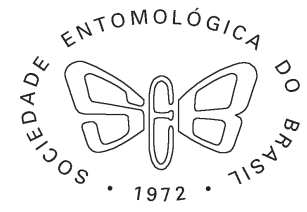

\section{ECOLOGY, BEHAVIOR AND BIONOMICS}

\section{Relocation of Croton sonderianus (Euphorbiaceae) Seeds by Pheidole fallax Mayr (Formicidae): a Case of Post-Dispersal Seed Protection by Ants?}

\author{
D LôBo, M TABARELLI, IR LEAL \\ Depto de Botânica, Univ Federal de Pernambuco, Recife, PE, Brasil
}

\section{Keywords}

Brazil, caatinga, myrmecochory, seed dispersal, semi-arid vegetation

\section{Correspondence}

INARA R LEAL, Depto de Botânica, Univ Federal de Pernambuco, Av. Professor Moraes Rego s/n, Cidade Universitária, 50670-901, Recife, PE, Brasil; irleal@ufpe.br

Edited by Kleber Del Claro - UFU

Received 10 February 2011 and accepted 29 March 2011

\begin{abstract}
Although seed dispersal by ants might reduce seed predation near the parent plants, predation on discarded seeds clustered on nest refuse piles may reduce any initial benefit provided by seed removal. Here we examine the fate of Croton sonderianus seeds that were discarded by Pheidole fallax Mayr ants on their nest refuses in caatinga vegetation of northeast Brazil. We collected all seeds discarded in refuse piles of 20 nests and within a radius of $50 \mathrm{~cm}$ from their borders, and examined them for evidence of predation. A total of 3,017 seeds were recorded either located in the P. fallax refuse piles $(89.1 \%)$ or nest vicinity $(10.9 \%)$. Predation was three fold higher in nest vicinity as compared to refuse piles. By removing seeds from beneath parent plants and relocating then to refuse piles, $P$. fallax is possibly providing double protection services for C. sonderianus seeds. Our findings represent the first evidence for predator-avoidance as benefit for plants resulting from ant seeddispersal in the neotropics.
\end{abstract}

\section{Introduction}

Ants frequently operate as effective dispersers for over 3,000 plant species with elaiosome-bearing seeds, from tropical to temperate habitats worldwide (Rico-Gray \& Oliveira 2007). Ants carry the seeds to their nests, remove and consume the elaiosomes, and discard/ concentrate the intact seeds in refuse piles either within subterranean nest chambers or on the soil surface around nest entrances (Beattie 1985). The benefits to plants of this mutualism include: directed dispersal to nutrientenriched site, reduced competition between seedlings and adults, improved germination in response to seed cleaning, and protection of seeds against predation and fire (Manzaneda et al 2005, Giladi 2006, Rico-Gray \& Oliveira 2007).

In a recent meta-analysis, Giladi (2006) concluded that seed protection is a frequent benefit for plants resulting from ant seed-dispersal - the author found support for the predator-avoidance hypothesis in $80 \%$ of the studies that examined this hypothesis. Predation can affect plant population dynamics, but also drives the evolution of many aspects of plant reproduction, particularly fruit and seed morphology (Manzaneda et al 2005). In this context, seed removal by ants has been proposed to reduce the chance of seeds being predated close to their parent plant (Rico-Gray \& Oliveira 2007). However, the discarding of seeds clustered in external refuse piles (Beattie 1985), which may attract higher predator activity, may reduce or even eliminate any initial benefit provided by seed removal from the vicinity of parent plants (Manzaneda et al 2005). This is especially relevant given that the ultimate destination of most seeds dispersed by ants is a refuse pile (Beattie 1985, Leal et al 2007), although some have been reported to be further re-dispersed around nests (Lubertazzi et al 2010). 
Here we examine the fate of Croton sonderianus seeds that were discarded by Pheidole fallax Mayr ants on their nest refuse piles. The Croton-Pheidole relationship is one of a myriad of interactions involving seeds and ants in the caatinga vegetation - a mosaic of scrub vegetation and dry forest that has been considered a hotspot of myrmecochory in South America (Leal et al 2007). Over $80 \%$ of seeds removed by ants in caatinga are discarded onto refuse piles and apparently are not re-dispersed (Leal 2003a, Leal et al 2007), which represent an opportunity to address post seed-dispersal predation and the role played by nest-mediated seed protection. As argued by Del-Claro \& Torezan-Silingardi (2009), insect-plant interactions may represent key mechanisms structuring the natural world.

\section{Material and Methods}

The study was carried out in a continuous patch of caatinga vegetation in the region of Parnamirim (8'05'26"S, 3934'42"W), Pernambuco state, northeast Brazil. The climate is typically semi-arid with a marked annual dry season (<60 mm per month) lasting 7-11 months (IBGE 1985). Annual rainfall is around $500 \mathrm{~mm}$, with the wettest period between April and August (IBGE 1985), but long lasting (2-3 years) periods of severe drought are frequent (Sampaio 1995). Predominant soils are non-calcic brown soils, regosols and planosols (IBGE 1985). The vegetation is a mosaic of physiognomic types ranging from patches of seasonally tropical dry forests (sensu Pennington et al 2000) to scrub vegetation (Sampaio 1995, Prado 2003).

Croton sonderianus is a pioneer shrub species bearing capsules with small ( $4.7 \pm 0.28 \mathrm{~mm}$ length; mean \pm SD) elaiosome-bearing seeds. Such tiny seeds are ballistically dispersed beneath and around parents, but subsequently removed and piled by ants, particularly species of Pheidole (Leal 2003a, Leal et al 2007). Pheidole fallax is widespread in the neotropics from Costa Rica to Argentina, especially in dry forests (Wilson 2003). Workers are seed harvesters and form conspicuous trunk trails to seed sources (Zelikova \& Breed 2008). In the caatinga, P. fallax is a very frequent species (Leal 2003b) and a legitimate myrmecochorous seed disperser, being responsible for up to $30 \%$ of all seeds removed by ants on the ground (Leal 2003a, Leal et al 2007). Additional information on Croton-Pheidole system is available in Passos \& Ferreira (1996).

In the rainy season of 2009, we assessed 20 nests of $P$. fallax sizing up to $2100 \mathrm{~cm}^{2}$ (calculated as an ellipsoid). Each nest area consisted of a nest entrance, a nest mound and a spatially well-delimitated and dense seed pile created by ant deposition (Fig 1). We collected

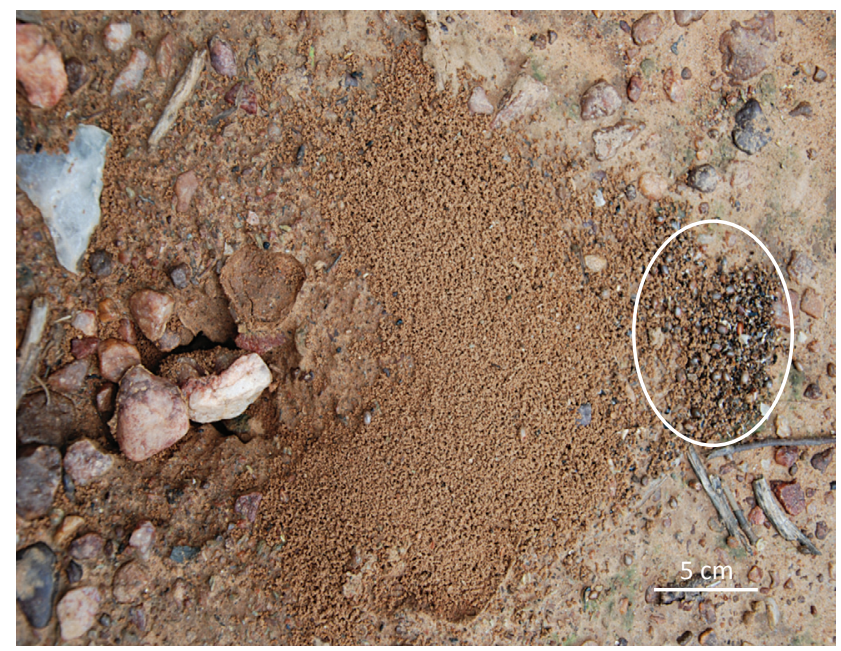

Fig $1 \mathrm{~A}$ Pheidole fallax nest area in the caatinga vegetation, northeast Brazil. A white circle highlights a well-delimited refuse pile with a concentration of Croton sonderianus seeds.

all ant-discarded seeds into associated nest refuse piles (treatment) and within a radius of $50 \mathrm{~cm}$ from the borders delimitating ant nests - i.e., the nest vicinity as a control site (as opposed to the area adjacent to the nest entrance, see Fig 1). Seeds in the nest vicinity were assumed to be released/lost by ants on their way to nests, or reached this location via other means (e.g. ballistic dispersal), but in all cases they consisted of single seeds already free of elaiosome (i.e. unattractive to ants).

Focal nests were located at least $10 \mathrm{~m}$ from any other ant nest (25.7 $\pm 12.5 \mathrm{~m}$ apart), and not located beneath the canopy of any Croton sonderianus shrub to (1) eliminate overlapping among colony foraging areas, and (2) reduce potential contamination of seed piles by seeds dropped directly from parents via ballistic dispersal. Seeds were counted and examined for the presence of predation traces (holes or seeds missing parts), and such traceable predation was compared between refuse piles and controls via a paired $t$ test and a contingency table (Zar 1999). Possible seed predation leaving no trace (e.g. potential seed ingestion by small rodents and granivorous birds) was not examined as such seeds could not be retrieved.

We adopted this spatial design because Pheidole foraging activities have been reported to achieve dozens of meters from colonies (Leal 2003a, Leal et al 2007, Zelikova \& Breed 2008). However, ant presence and activity is spatially concentrated around nest entrance and mound because (1) ants present central place foraging and always return to the nest for feeding the nestmates and/or store preys, and (2) majors workers (i.e. soldiers) permanently defend the nest area to protect the colony (Itzkowitz \& Haley 1983, Hölldobler \& Wilson 1990). Although ants are not involved in active seed protection, seed predators (and other organisms as 
well) are expected to be deterred by resident ants in case they get too close to the nest entrance (i.e. ownership behaviour sensu Way 1963). Such indirect nest defence is clearly most pronounced near the nest entrance but may also occasionally occur at other spots; i.e. a sort of nestdependent and permanent protection vs. an occasional protection conferred to other sites such as our control (personal observation).

\section{Results}

A total of 3,017 seeds $C$. sonderianus were recorded either located in the P. fallax refuse piles (89.1\%) or nest vicinity (10.9\%). Refuse piles contained between 41 and 283 seeds, whereas seeds outside piles always occurred singly, but achieved 7 to 29 within controls. Refuse piles also contained: (1) other myrmecochorous seeds from species of Manihot, Jatropha, Cnidoscolos (all Euphorbiaceae), Tacinga (Cactaceae) and Commiphora (Burseraceae); (2) over 200 fragments of ant species from the genera Dinoponera, Camponotus, Cephalotes and other species of Pheidole, and (3) the remains of at least 16 species of Coleoptera (i.e. remains of preys of Pheidole fallax). Among piles and controls, only a small fraction $(5.6 \%)$ of seeds exhibited signs of predation, with holes from bruchid beetles being the most common. However, predation was three fold higher in nest vicinity (13.04 \pm $15.3 \%)$ as compared to refuse piles $(4.5 \pm 3.1 \%)(t=2.44$, $\mathrm{df}=19, \mathrm{P}=0.012$ ) (Fig 2). Precisely, seed predation varied from $2.1 \%$ to $13.4 \%$ in piles, but reached up to $50 \%$ in a control spot; such chances however were not correlated to seed abundance. Consequently, the total number of predated seeds (pooling all the nests) was significantly higher in nest vicinity $(11.8 \%)$ as compared to refuse piles $(4.8 \%)\left(\chi^{2}=28.8, \mathrm{df}=1, \mathrm{P}<0.0001\right)$; a difference that resulted on the presence of 2,557 intact seeds stored across the 20 nests of $P$. fallax.

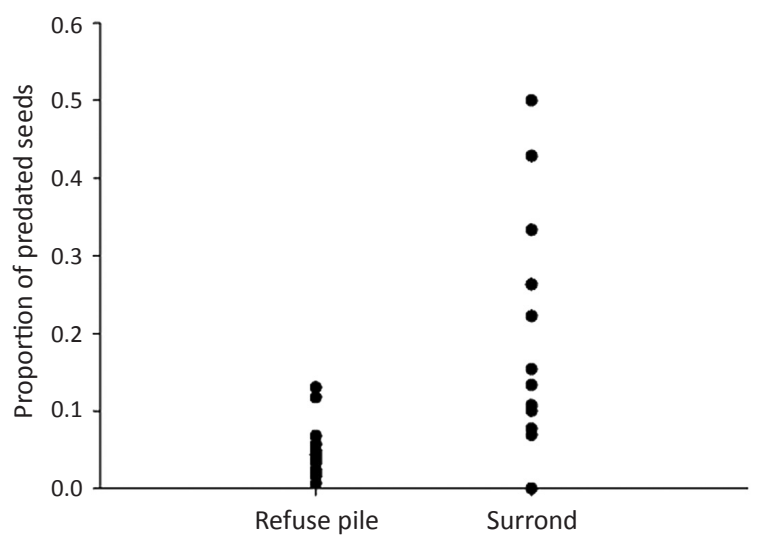

Fig 2 Proportion of Croton sonderianus seeds predated in nest refuse piles of Pheidole fallax and within a radius of $50 \mathrm{~cm}$ from the borders of ant nests.

\section{Discussion}

Our results indicate that $P$. fallax relocates considerable numbers of Croton sonderianus seeds (up to 2,500 seeds ha $^{-1}$ according to data on nest density), and by discarding them in nest refuse piles, seeds experience a higher per capita chance of escaping from predation (at least traceable predation), despite seed aggregation.

Rodents, granivorous ants, but mainly bruchid beetles, have been recognized as effective predators of myrmecochorous seeds (Hughes \& Westoby 1990, Ohara \& Higashi 1987, Ohkawara et al 1996, 1997), including in the caatinga vegetation (personal observation). Pheidole fallax is an aggressive predator with nests protected by a specialized sub-cast of ants, the majors (Itzkowitz \& Haley 1983). This sort of nest protective behaviour is likely to deter many types of organisms (including granivores) that could potentially destroy piled seeds (e.g. Coleoptera species as suggested by nest remains). In fact, it represents so far the most parsimonious mechanism to account for the differential predation we documented across 20 nest refuses although the role played by potential seed predators (e.g. small rodents and granivorous birds) remains not examined in the caatinga vegetation. This mechanism remains valid even if we assume that ants may occasionally deter seed predators across our control sites.

The predator-avoidance hypothesis has already received some support, mostly in temperate forests (Heithaus 1981, Higashi et al 1989) and sclerophyll vegetation (Hughes \& Westoby 1990), while our findings represent the first evidence from the neotropics (but see Passos \& Oliveira 2004 for seedling protection by a Neotropical ant species). Furthermore, the classical evidence of predator-avoidance refers to ant-mediated removal of those seeds that eventually drop around parents, which reduces the chance of seeds being detected by predators (Heithaus 1981, Higashi et al 1989, Smith et al 1989, Ohkawara \& Higashi 1994, Ohkawara et al 1997), while $P$. fallax services include not only seed-removal from parental spots, but mainly seed discarding/piling plus nest-mediated protection.

How might the protection services provided by $P$. fallax ants affect $C$. sonderianus recruitment and demography? Croton sonderianus is a deciduous plant, with the start of leaf-fall synchronized with the onset of the dry season (Machado et al 1997). Flowering, fruiting and ballistic seed dispersal occurs over the rainy season (Griz \& Machado 2001), with dispersed seeds, if not predated, remaining dormant up to the first rains of the next rainy season. This means that seeds remain exposed to predation for 9-10 mo, a risk that can be reduced by $P$. fallax seed protection. This protective service (favouring thousands of seeds) add to others benefits provided for Pheidole ants in the caatinga vegetation (including $C$. 
sonderianus) such as the provision of nutrient-enriched nest soils, which support increased seed germination and seedling survival; i.e. directed-dispersal hypothesis (Leal et al 2007). In this context it is reasonable to propose that such combination of services improves Croton recruitment even if we accept that density-dependent mechanisms negatively impact seed/seedling survivorship across nest seed piles, what reinforce the overall role played by ants as key dispersers of myrmecochorous seeds in the caatinga vegetation.

\section{Acknowledgments}

This study was carried out during the 2009 caatinga field course supported by the CAPES (PROCAD 0166057). We are very grateful to Jacques Delabie for ant species identification. Alan Andersen and Martin Pfeiffer provided helpful criticisms on the manuscript.

\section{References}

Beattie AJ (1985) The evolutionary ecology of ant-plant mutualisms. Cambridge, Cambridge University Press, 182p.

Del-Claro K, Torezan-Silingardi HM (2009) Insect-plant interactions: new pathways to a better comprehension of ecological communities in Neotropical savannas. Neotrop Entomol 38: 159-164.

Giladi I (2006) Choosing benefits or partners: a review of the evidence for the evolution of myrmecochory. Oikos 112: 481-492.

Griz LMS, Machado IC (2001) Fruiting phenology and seed dispersal syndromes in caatinga, a tropical dry forest in the Northeast of Brazil. J Trop Ecol 17: 303-321.

Heithaus ER (1981) Seed predation by rodents on three antdispersed plants. Ecology 62: 136-145.

Higashi S, Tsuyuzaki S, Ohara M, Ito F (1989) Adaptive advantages of ant-dispersed seeds in the myrmecochorous plant Trillium tschonoskii (Liliaceae). Oikos 54: 389-394.

Hölldobler B, Wilson EO (1990) The ants. Cambridge, Harvard University Press, 732p.

IBGE (1985) Atlas nacional do Brasil: Região Nordeste. Rio de Janeiro, IBGE.

Itzkowitz M, Haley M (1983) The food retrieval tactics of the ant Pheidole fallax Mayr. Insect Soc 30: 317-322.

Hughes L, Westoby M (1990) Removal rates of seeds adapted for dispersal by ants. Ecology 71: 138-148.

Leal IR (2003a) Dispersão de sementes por formiga na caatinga, p.593-624. In Leal IR, Tabarelli M, Silva JMC (eds) Ecologia e conservação da caatinga. Recife, Editora da Universidade Federal de Pernambuco, 806p.

Leal IR (2003b) Diversidade de formigas em diferentes unidades de paisagem da caatinga, p.435-461. In Leal IR, Tabarelli M, Silva
JMC (eds) Ecologia e conservação da caatinga. Recife, Editora da Universidade Federal de Pernambuco, 806p.

Leal IR, Wirth R, Tabarelli M (2007) Seed dispersal by ants in the semi-arid caatinga of Northeast Brazil. Ann Bot 99: 885-894.

Lubertazzi D, Lubertazzi MAA, Mccoy N, Gove AD, Majer JD, Dunn RR (2010) The ecology of a keystone seed disperser, the ant Rhytidoponera violace. J Insect Sci 10: 158.

Machado IC, Barros LM, Sampaio EVSB (1997) Phenology of caatinga species at Serra Talhada, PE, Northeastern Brazil. Biotropica 29: 57-68.

Manzaneda AJ, Fedriani JM, Rey PJ (2005) Adaptive advantages of myrmecochory: the predator-avoidance hypothesis tested over a wide geographic range. Ecography 28: 583-592.

Ohara M, Higashi S (1987) Interference by ground beetles with the dispersal by ants of seeds of Trillium species (Liliaceae). J Ecol 75: 1091-1098.

Ohkawara K, Higashi S (1994) Relative importance of ballistic and ant dispersal in two diplochorous Viola species (Violaceae). Oecologia 100: 135-140.

Ohkawara K, Higashi S, Ohara M (1996) Effects of ants, ground beetles and the seed-fall patterns on myrmecochory of Erythronium japonicum Decne (Liliaceae). Oecologia 106: 500506.

Ohkawara K, Ohara M, Higashi S (1997) The evolution of ant-dispersal in a spring-ephemeral Corydalis ambigua (Papaveraceae): timing of seed-fall and effects of ants and ground beetles. Ecography 20: 217-223.

Passos L, Ferreira SO (1996) Ant dispersal of Croton priscus (Euphorbiaceae) seeds in a tropical semideciduous forest in Southeatern Brazil. Biotropica 28: 697-700.

Passos L, Oliveira PS (2004) Interaction between ants and fruits of Guapira opposite (Nyctaginaceae) in a Brazilian sandy plain rainforest: ant effects on seeds and seedlings. Oecologia 139: 376-382.

Pennington RT, Prado DE, Pendry CA (2000) Neotropical seasonally dry forests and Quaternary vegetation changes. J Biogeogr 27: 261-273.

Prado DE (2003) As caatingas da América do Sul, p.3-74. In Leal IR, Tabarelli M, Silva JMC (eds) Ecologia e conservação da caatinga. Recife, Editora da Universidade Federal de Pernambuco, 806p.

Rico-Gray V, Oliveira PS (2007) The ecology and evolution of antplant interactions. Chicago, University of Chicago Press, 320p.

Sampaio EVSB (1995) Overview of the Brazilian caatinga, p.35-63. In Bullock S H, Mooney HA, Medina E (eds) Seasonal dry tropical forests. Cambridge, Cambridge University Press, 450p.

Smith BH, Forman PD, Boyd AE (1989) Spatial patterns of seed dispersal and predation of two myrmecochorous forest herbs. Ecology 70: 1649-1656.

Way MJ (1963) Mutualism between ants and honeydew-producing Homoptera. Annu Rev Entomol 8: 307-44. 
Wilson EO (2003) Pheidole in the new world: a dominant, hyperdiverse ant genus. Cambridge, Harvard University Press, $818 \mathrm{p}$.

Zar JH (1999) Biostatistical analysis. (Fourth edition). London, Prentice-Hall, 931p.
Zelikova TJ, Breed MD (2008) Effects of habitat disturbance on ant community composition and seed dispersal by ants in a tropical dry forest in Costa Rica. J Trop Ecol 24: 309-316. 